DOI: $10.14720 /$ aas.2016.107.2.14

Agrovoc descriptors: Aphididae, Aphis gossypii, greenhouse crops, protected cultivation, cucumbers, pest control, insect control, insecticides, ecological control

Agris category code: $\mathrm{H} 01, \mathrm{H} 10$

\title{
Bioefficacy of some biorational insecticides for the control of Aphis gossypii Glover, 1877, (Hemiptera: Aphididae) on greenhouse grown cucumber
}

\author{
Mohammad Saeed EMAMI
}

Received June 31, 2016; accepted September 09, 2016.

Delo je prispelo 31. junij 2016, sprejeto 09. september 2016.

\begin{abstract}
Aphis gossypii Glover, 1877 is a serious pest of cucumber in greenhouse plantings. Biorational insecticides are an alternative of broad spectrum insecticides for aphid suppression in greenhouse. In this regards, the efficiency of some biorational insecticides including soap based on coconut oil, surfactant based on sodium sulfosuccinate and antifeeding based on potassium nicotinate were assayed on A. gossypii in the cucumber greenhouse. The trials were set up in a randomized complete block design with four replications. Samplings were carried out one day before spraying and 3, 7, 14 and 21 days after spraying. The data were submitted to ANOVA and the means comparison was performed using Duncan's test. The results indicated that the highest mortality in insecticidal soap, surfactant and antifeeding treatments occurred after 3 days, with $78.47 \%, 67.16 \%$ and $60.48 \%$ mortality, respectively. The results of the trials are discussed in terms of improving management of the populations of $A$. gossypii.
\end{abstract}

Key words: A. gossypii, biorational insecticides, antifeeding, soap, surfactant, cucumber

\section{IZVLEČEK}

UČINKOVITOST OKOLJU PRIJAZNIH INSEKTICIDOV ZA ZATIRANJE BOMBAŽEVČEVE UŠI (Aphis gossypii Glover, 1877, Hemiptera: Aphididae) NA KUMARAH GOJENIH V RASTLINJAKU

Bombaževčeva uš (Aphis gossypii Glover, 1877) je pomemben škodljivec kumar, gojenih $\mathrm{v}$ rastlinjaku. Okolju prijazni insekticidi so dobra alternativa insekticidom širokega spectra za zatiranje uši v rastlinjakih. V ta namen so bili za zatiranje omenjene uši na kumarah, gojenih v rastlinjaku, uporabljeni trije okolju prijazni insekticidi, in sicer insekticidno milo na osnovi kokosovega olja, snov za zmanjševanje površinske napetosti na osnovi natrijevega sulfosukcinata in zaviralec prehranjevanja na osnovi kalijevega nikotinata. Poskus je bil zastavljen kot naključni bločni poskus s štirimi ponovitvami. Vzorčenja so bila opravljena dan pred in $3,7,14$ in 21 dni po škropljenju. Podatki so bili obdelani z ANOVA, primerjava povprečij pa z Duncanovim preizkusom. Rezultati so pokazali, da je bila največja smrtnost zaradi insekticidnega mila, snovi za zmanjševanje površinske napetosti in zaviralca prehranjevanja ugotovljena tri dni po uporabi z $78.47 \%$, $67.16 \%$ in $60.48 \%$ smrtnostjo. Rezultati poskusa so ovrednoteni v smeri učinkovitejšega zatiranja uši A. gossypii.

Ključne besede: A. gossypii, okolju prijazna sredstva za varstvo rastlin, zaviralci prehranjevanja, insekticidno milo, površinska napetost, kumare

\section{INTRODUCTION}

Cucumber is one of the major important greenhouse crops which is annually grown extensively. The area of cucumber culture in Iran consists of 70,000 hectares with production of about 1,600,000 tonnes (Faostat, 2013). At the present time, cucumber cultivation in greenhouses has been expanded in many areas of Iran, and Aphis gossypii Glover, 1877 is observed in a large number of cucumber greenhouses. It has a worldwide distribution and a wide range of host

Department of Plant Protection, Isfahan Research and Education Center for Agriculture and Natural Resources, Agricultural Research, Education and Extension Organization (AREEO), Isfahan, Iran; PO Box 81785-199, Isfahan, Iran; e-mail: mse1480@gmail.com 
plants (Kresting et al., 1999). A. gossypii can quickly build up a large population on greenhouse grown cucumber and causes considerable economic damage by sucking sap directly from the phloem, producing honeydew and transmission of plant viruses (Perng, 2002). Generally, the control of A. gossypii has relied on a wide array of chemical insecticides which adversely affect non target organisms, are environmentally dangerous and insects frequently build up resistance to them (Wang et al., 2002, Cao et al., 2008). A considerable challenge versus greenhouse cucumber consumers is the subject of food security and healthiness. Therefore there is a real need to assay biorational insecticides which are environmentally safe, non-toxic to man, quickly decomposable and pests do not become resistant after long apply period (Khater, 2012). Biorational insecticides are synthetic and/or natural materials that are more choosey and environmentally friendly and proper to be combined in pest management programs founded on integration of biological and chemical control methods (Horowitz and Ishaaya, 2004). Soaps, surfactant and antifeedings are some biorational substances (Schuster and Stansly, 2009). Insecticidal soaps are founded on potassium fatty acids and are applied to control many crop pests (Miller and Uetz, 1998; Trdan et al., 2006). Applying insecticidal soap exhibited significant suppression of rosy apple aphid, Dysaphis plantaginea (Passerini, 1860), green aphid, Aphis pomi (DeGeer, 1773) and the spirea aphid, Aphis spiraecola Patch, 1914 (Lawson and Weires, 1991). Karagounis et al. (2006) demonstrated that insecticidal soap as replacement for chemical insecticide (imidacloprid) was satisfactory for controlling of
Myzus persicae (Sulzer, 1776) on organically grown peaches. Fournier and Brodeur (2000) demonstrated that insecticidal soap meaningfully reduced the population of the potato aphid, Macrosiphum euphorbiae Thomas, 1878, the green peach aphid, and the lettuce aphid Nasonovia ribisnigri (Mosley, 1841) in greenhouse experiments. Dioctyl sodium sulfosuccinate is an anionic surfactant and is used as an emulsifier, dispersant, wetting agent and an adjuvant in insecticide formulations (Pesticides Database, 2014). Field experiments on the pear psyllid, Psylla pyri (L., 1758) and the strawberry mite, Tarsonemus pallidus (Zimmermann, 1905) and glasshouse experiments on the two-spotted spider mite, Tetranychus urticae Koch, 1836 demonstrated that dioctyl sulfosuccinate exhibited significant control of these pests (Bylemans and Van Goethem, 1996). Nicotine is a strong antifeeding agent, which leads to decrease consumption even pests adapted to nicotine and it also prevents pests from feeding (Steppuhn and Baldwin, 2007). Antifeeding is a product containing of potassium nicotinate that is applied as an antifeedant to efficient control of sucking pests such as aphids and aleurodids (Grabi, 2015). Pymetrozine choicely prevent feeding in aphids which therefore causes starvation (Fluckiger et al., 1992, Kayser et al., 1994). Pymetrozine is presently utilized in aphids IPM program in agricultural crops (Smagghe et al., 2010). The present study aimed to assay the efficacy of biorational insecticides including insecticidal soap, surfactant and antifeeding for using in cucumber greenhouse plantings in connection with their potential to control A. gossypii.

\section{MATERIALS AND METHODS}

\subsection{Site, plants and insecticides}

Field studies were performed in $1000 \mathrm{~m}^{2}$ greenhouses cucumber located at Isfahan (Central Iran), during the 2012-13 growing seasons under environmental conditions of $27 \pm 3{ }^{\circ} \mathrm{C}, 70 \pm 5 \%$ RH and L:D 16:8 h. The plants were 45 days old, Cucumis sativus L. of the variety 'Storm', which is the common cucumber variety in the study area. Management operations including control of other pests, fertilization and irrigation were carried out similarly on all trial plants. Three biorational insecticides including soap based on coconut oil (Palizin ${ }^{\circledR} 65 \%$ SL, Kimia Sabzavar) at a dose of $3 \mathrm{~g} / \mathrm{l}$, surfactant based on sodium sulfosuccinate (D-octil ${ }^{\circledR} 70 \%$ SL, A.M.C.) at a dose of $0.3 \mathrm{~g} / 1$ and antifeeding based on potassium nicotinate (Antifeeding ${ }^{\circledR} 10 \% \mathrm{SL}$, Grabi) at a dose of $3 \mathrm{~g} / \mathrm{l}$ and the insecticide pymetrozine $(50 \% \mathrm{WG}$, Golsam) at a dose of $1 \mathrm{~g} / \mathrm{l}$ were used. 


\subsection{Experimental design}

The experiment was laid out in a randomized complete block design with four replications. Each replication included 20 plants separated from the adjacent treatment by a border plant. Treatments were four insecticides and untreated check which were randomly placed in any of the blocks. All treatments were performed by a motorized sprayer (Zeeba Co.) at a pressure of $30 \mathrm{~kg} / \mathrm{cm}^{2}$ using a cone nozzle. The experimental plants were sprayed at a volume rate of $4001 \mathrm{ha}^{-1}$. A single application of each treatment was applied. The sprayer was washed with water and surfactant before applying each treatment. Check plants were sprayed with drink water. Spraying was carried out when most of the plants have been infested by the pest (an average of 15.16 and 12.49 aphids per leaf in 2012 and in 2013, respectively). Spraying was started at 9:00 a.m. and continued up to 11:00 a.m.

\subsection{Sampling}

The sampling was done in five steps including a day before treatment, 3, 7, 14 and 21 days posttreatment. For sampling, fifteen plants were randomly selected and the numbers of live aphids on both surfaces of the third leaf from the top of the plant were carefully enumerated with a $4 \mathrm{x}$ magnification hand lens. All nymphal stages and adults were enumerated.

\subsection{Data analyses}

Mean population density of pest was computed at any experiment unit and pest mortality percentage for any of the treatments was achieved in every sampling step according to the following model (Henderson and Tilton, 1955):

$M=100 \times(1-(T a \times C b) /(T b \times C a)$

where, $M$, is the mortality percentage, $T a, C b, T b$, and $\mathrm{Ca}$ are the number of aphids live in treated plot after treatment, in check plot before treatment, in treated plot before treatment, and in check plot after treatment, respectively. The data of mortality percentages were transferred to arc-sine where, $M$, is the mortality percentage, $T a, C b, T b$, and $C a$ are the number of aphids live in treated plot after treatment, in check plot before treatment, in treated plot before treatment, and in check plot after treatment, respectively. The data of mortality percentages were transferred to arc-sine $\sqrt{x / 100}$ before analysis. All data were submitted to a oneway ANOVA analysis to compare the effect of treatments on aphid population. The comparison of means was done using Duncan's multiple range test (DMRT) $(P<0.05)$. Data were analysed by using SAS statistical software version 9.1. (SAS Institute Inc. 2004).

\section{RESULTS}

\subsection{Aphid population before spraying}

There was not a significant difference among treatments in aphid density before spraying $\left(F_{4,12}=\right.$ $1.53 ; p=0.26$, in 2012 and $F_{4,12}=1.45 ; p=0.28$, in 2013), indicating uniformity in population of the aphid in all the trial plots. Overall mean of $A$. gossypii in treatments was 15.16 and 12.49 aphids per leaf in 2012 and 2013, respectively (Tables 1 and 2). No signs of phytotoxicity at recommended field rates were seen on the experimental plants during the trial. 
Table 1: Mean number of Aphis gossypii per leaf in various treatments at days before and after spraying in 2012

\begin{tabular}{cccccc}
\hline \multirow{2}{*}{ Treatments } & \multicolumn{5}{c}{ Mean \pm SE } \\
\cline { 2 - 6 } & 1 DBT & 3 DAT & 7 DAT & 14 DAT & 21 DAT \\
\hline Pymetrozine & $14.68 \pm 0.86$ & $0.00 \pm 0.00$ & $0.03 \pm 0.02$ & $0.18 \pm 0.02$ & $0.60 \pm 0.07$ \\
Soap & $16.82 \pm 1.01$ & $0.72 \pm 0.23$ & $1.70 \pm 0.04$ & $3.35 \pm 0.11$ & $7.58 \pm 0.33$ \\
Detergent & $14.28 \pm 1.47$ & $2.22 \pm 0.18$ & $3.70 \pm 0.21$ & $5.83 \pm 0.07$ & $7.82 \pm 0.59$ \\
Anti-Feeding & $14.85 \pm 1.07$ & $3.88 \pm 0.16$ & $4.23 \pm 0.18$ & $5.88 \pm 0.21$ & $7.27 \pm 0.20$ \\
Mean & $15.16 \pm 0.57$ & - & - & - & - \\
\hline
\end{tabular}

DBT is a day before treatment and DAT is days after treatment.

Table 2: Mean number of Aphis gossypii per leaf in various treatments at days before and after spraying in 2013

\begin{tabular}{cccccc}
\hline \multirow{2}{*}{ Treatments } & \multicolumn{5}{c}{ Mean \pm SE } \\
\cline { 2 - 6 } & 1 DBT & 3 DAT & 7 DAT & 14 DAT & 21 DAT \\
\hline Pymetrozine & $12.98 \pm 0.40$ & $0.03 \pm 0.02$ & $0.05 \pm 0.02$ & $0.12 \pm 0.02$ & $1.33 \pm 0.06$ \\
Soap & $12.65 \pm 0.11$ & $0.88 \pm 0.09$ & $1.70 \pm 0.04$ & $2.68 \pm 0.16$ & $6.47 \pm 0.19$ \\
Detergent & $12.87 \pm 0.37$ & $2.08 \pm 0.11$ & $3.42 \pm 0.20$ & $5.70 \pm 0.11$ & $7.48 \pm 0.20$ \\
Anti-Feeding & $12.25 \pm 0.23$ & $3.42 \pm 0.16$ & $3.88 \pm 0.13$ & $5.48 \pm 0.22$ & $6.12 \pm 0.24$ \\
Mean & $12.49 \pm 0.21$ & - & - & - & - \\
\hline
\end{tabular}

DBT is a day before treatment and DAT is days after treatment.

\subsection{Effect of the treatments three days after spraying}

There was a significant difference among treatments in terms of percent mortality after three days $\left(F_{3,9}=148.32, P<0.0001\right.$, in 2012 and $F_{3,9}=$ 186.63, $P<0.0001$, in 2013). The mean of $A$. gossypii per leaf for each treatment is given in Tables 1 and 2. The comparison of the mortality percentage means showed that the treatments categorized into four groups (Figures 1 and 2). The highest mortality percentage among biorational insecticides was obtained in soap treatment with an average of $78.47 \%$ and $75.78 \%$ in 2012 and 2013, respectively (Figures 1 and 2).

\subsection{Effect of the treatments seven days after spraying}

There was a significant difference among treatments in percent mortality after seven days $\left(F_{3,9}=104.7, P<0.0001\right.$ in 2012 and $F_{3,9}=296.24$, $P<0.0001$, in 2013). The mean of A. gossypii per leaf for each treatment is given in Tables 1 and 2 . The comparison of the mortality percentage means showed that the treatments categorized into three groups (Figures 1 and 2). The highest mortality percentage among biorational insecticides was obtained in soap treatment with an average of $71.93 \%$ and $70.43 \%$ in 2012 and 2013, respectively (Figures 1 and 2). There was not a significant difference between two other biorational insecticides, surfactant and antifeeding, so they were categorized to the same group with the least mortality percentage (Figures 1 and 2).

\subsection{Effect of the treatments 14 days after spraying}

There was a significant difference among treatments in percent mortality after 14 days $\left(F_{3,9}=\right.$ 147.97, $P<0.0001$, in 2012 and $F_{3,9}=271.94, P<$ 0.0001 in 2013). The mean of A. gossypii per leaf for each treatment is given in Tables 1 and 2. The comparison of the mortality percentage means showed that the highest mortality percentage among biorational insecticides was obtained in soap treatment with an average of $64.23 \%$ and $65.12 \%$ in 2012 and 2013, respectively (Figures 1 and 2). Two other biorational insecticides had the same mortality percentage (Figures 1 and 2). 


\subsection{Effect of the treatments 21 days after spraying}

A significant difference was found in the mortality percentages among different treatments $\left(F_{3,9}=\right.$ 156.58, $P<0.0001$, in 2012 and $F_{3,9}=190.52, P<$ 0.0001 , in 2013). The mean of A. gossypii per leaf for each treatment is given in Tables 1 and 2. The comparison of the mortality percentage means showed that the highest mortality percentage among biorational insecticides was obtained in soap treatment with an average of $48.77 \%$ in 2012 (Figure 1). There was not a significant difference between two biorational insecticides, soap and antifeeding, in the mortality percentage in 2013 (Figure 2).

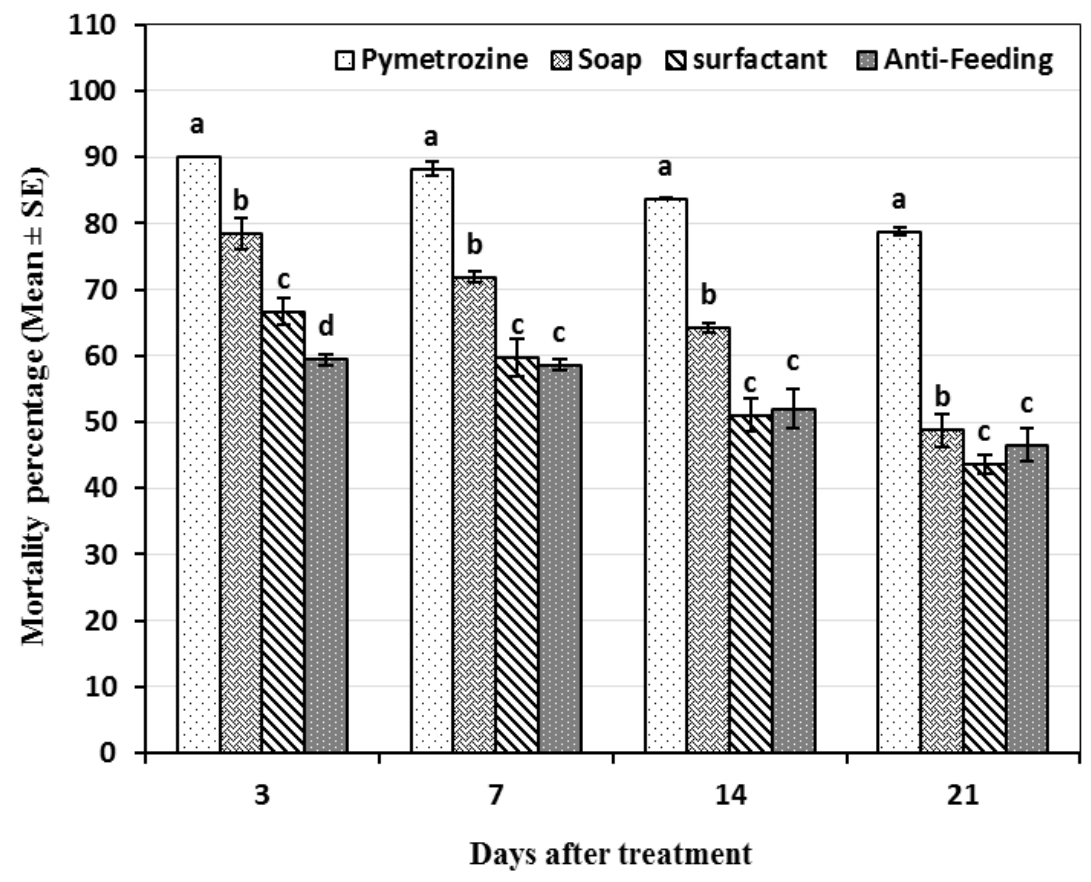

Figure 1: The mortality percentage of Aphis gossypii at different days after spraying in the greenhouse in 2012 . Means followed by the same letters in each day after spraying was not significantly different $(P<0.05)$. 


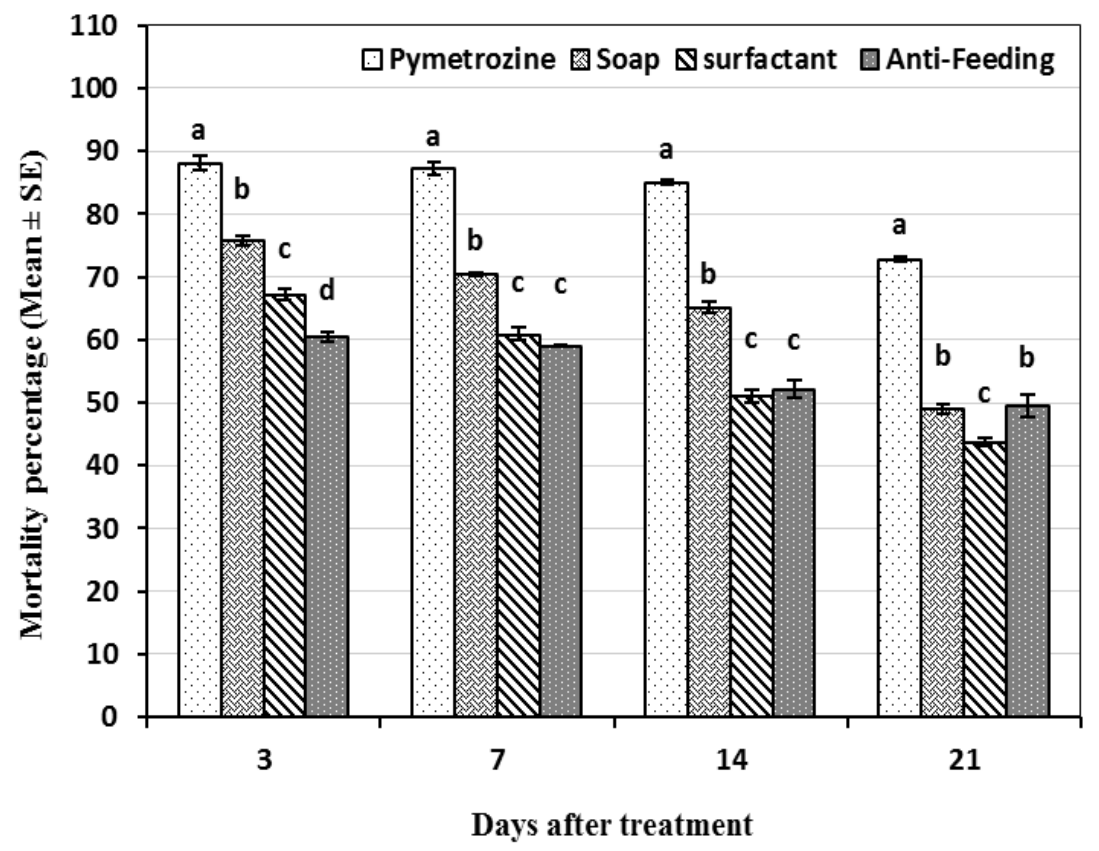

Figure 2: The mortality percentage of Aphis gossypii at different days after spraying in the greenhouse in 2013. Means followed by the same letters in each day after spraying was not significantly different $(P<0.05)$.

\section{DISCUSSION}

Insecticides differ in their toxicity and in their potential ecological effect. Biorational insecticides are relatively non-toxic to consumers with little environmental contamination. According to the US-Environmental Protection Agency biorational insecticides display minimal risk to the environment, break down quickly, have minimal residue, are safe to applier and relatively small amounts are needed for successful control (Sadeghi et al., 2009). The findings of the present study revealed that pymetrozine had the highest effect on A. gossypii (Figures 1 and 2). It gave promising results in control of $A$. gossypii up to 21 days after spraying (Figures 1 and 2). Mojeni and Rezwani (2000) explained that pymetrozine had the highest efficacy for suppression of $A$. gossypii in field trials. The low effect of pymetrozine on natural enemies shows it a desirable insecticide for IPM programs (Fluckiger et al., 1992, Follas and Blanc, 1995). Insecticidal soaps based on fatty acid salts are contact insecticides with minimal adverse effects that suppress small pests through suffocation (by blocking the spiracles) or disruption of cuticular waxes and membranes in the integument, causing to desiccation (Isman,
2006). Here, the greenhouse experiments in both years revealed that the insecticidal soap significantly reduced the population of A. gossypii, three days after spraying (Figures 1 and 2). Regarding to mean aphid mortality, spraying the insecticidal soap on leaves reduced the aphid populations in cucumber plants comparably with surfactant and antifeeding. It gave promising results in suppression of $A$. gossypii up to 14 days after spraying (Figures 1 and 2). Other studies demonstrated that the insecticidal soaps are efficient against the aphid pest populations (Pinnock et al., 1974, Moore et al., 1979, Koehler et al., 1983, Lawson and Weires, 1991, Lee et al., 2005, Karagounis et al., 2006, Baniameri, 2008). McKenzie and Puterka (2004) and Hall and Richardson (2013) showed that the use of insecticidal soap provided significant control of the psyllid pest population, Diaphorina citri Kuwayama, 1908. Insecticidal soaps usually caused meaningful, but short-period suppression of some important pests such as wheat aphid, Schizaphis graminum (Rondanni, 1852) (Nuessly and Nagata, 2005), the thrips of weeping ficus, Gynaikothrips uzeli Zimmerman, 1900 (Held and 
Wheeler, 2007), aphid of the crepe myrtle, Tinocallis kahawaluokalani Kirkaldy, 1906 (Layton and $\mathrm{Gu}, 2009 \mathrm{a}$ ), whitefly of sweet potato, Bemisia tabaci (Gennadius, 1889) (Layton and Gu, 2009b) and the psyllid of pistachio, Agonoscena pistaciae Burckhardt and Lauterer, 1989 (Kabiri and Amiri-Besheli, 2012). The maximal mortality percentage in surfactant treatment, dioctyl sodium sulfosuccinate, occurred in three days after spraying (Figures 1 and 2). The present results are consistent with finding reported by Ranaei et al., (2012) that showed the mortality of aphids was $67.13 \%$ by deioctyl sodium sulfosuccinate. Dioctyl sodium sulfosuccinate, apart from its wetting activity, has also ovicidal, larvicidal and insecticidal effect upon mites, psyllids, aphids and scale insects (Dincsoy, 2013). However, the greenhouse experiments indicated that the use of soaps, surfactants and antifeedings can give some level of aphid suppression under commercial greenhouse conditions (Figures 1 and 2). Given the results, it would be more desirable to utilize these biorational compounds at preliminary phases of aphid infestation in joining with an aphid monitoring plan. In conclusion, according to the findings of the present research, little or no harmful impacts on lady beetles (Tremblay et al., 2008, Hall and Richardson, 2013) has been observed, using in organic and sustainable agriculture (Karagounis et al., 2006). Increasing market value for insecticide residue free products, usable around the harvest, action to slow down or minimize pest resistance to synthetic insecticides (Fournier and Brodeur, 2000) and no residual insecticidal activity (Baldwin, 2008), the insecticidal soap as a biorational insecticide could be suggested for the suppression of A. gossypii in cucumber greenhouse plantings in an IPM program.

\section{REFERENCES}

Baldwin, R. 2008. Soaps as insecticides. In: Capinera JL, Editor. Encyclopedia of Entomology. 2nd Ed. V. 1-4. Dordrecht, Netherlands: Springer; pp. 34333439.

Baniameri, V. 2008. Study of the efficacy of different concentrations of insecticidal soap, in comparison oxydemeton-methyl to control Aphis gossypii in greenhouse cucumber. IOBC/wprs Bull. 32:13-16.

Bylemans, D., Van Goethem, L. 1996. Possibilities of azadirachtin and salts of dioctylsulfo-succinate for the control of Psylla pyri, Tetranychus urticae and Tarsonemus pallidus. 49th International Symposium on Crop Protection; Ghent, Belgium, 61:871-876.

Cao, C. W., Zhang, J., Gao, X. W., Liang, P., Guo, H. L. 2008. Overexpression of carboxyl esterase gene associated with organophosphorus insecticide resistance in cotton aphids, Aphis gossypii (Glover). Pest. Biochem. Physiol. 90:175-180. Doi: 10.1016/j.pestbp.2007.11.004

Dincsoy, D. 2013. Special organic product: D-OCTIL. Available from: http://www.alibaba.com/productdetail/UPON-EQUEST_112308109.html.

Faostat. 2013. Faostat database results. The food and agriculture organization of the United Nations (FAO). Available from: http://www.faostat3.fao.org.
Fluckiger, C. R., Kristinsson, H., Senn, R., Rindlisbacher, A., Buholzerand, H., Voss, G. 1992. CGA215'944: A novel agent to control aphids and whiteflies. Crop Prot. Conf. Pests and Diseases; Brighton, 1:43-50.

Follas, G., Blanc, S. 1995. Control of aphids in tomatoes and brassicas with pymetrozine. 4th Plant Protection Conf.; New Zealand, 94:125.

Fournier, V., Brodeur, J. 2000. Dose-responses susceptibility of pest aphids (Homoptera: Aphididae) and their control on hydroponically grown lettuce with the entomopathogenic fungus Verticillium lecanii, azadirachtin and insecticidal soap. Environ. Entomol. 29:568-578. Doi: 10.1603/0046-225X-29.3.568

Grabi. 2015. Bioinducer antifeeding. Available from: http://www.grabichemical.it

Hall, D. G., Richardson, M. L. 2013. Toxicity of insecticidal soaps to the Asian citrus psyllid and two of its natural enemies. J. Appl. Entomol. 137:347-354. Doi: $\quad 10.1111 / \mathrm{j} .1439-$ 0418.2012.01749.x

Held, D. W., Boyd, D. W. J, Wheeler, C. 2007. Comparison of various insecticides for control of Gynaikothrips uzeli inside galls. Arthropod Manag. Tests. 33:G35. Doi: 10.1093/amt/33.1.G35

Acta agriculturae Slovenica, 107 - 2, september 2016 
Henderson, C. F., Tilton, E. W. 1955. Tests with acaricides against the brown wheat mite. J Econo Entomol. 48:157-161. Doi: 10.1093/jee/48.2.157

Horowitz, A. R., Ishaaya, I. 2004. Biorational insecticides: mechanisms, selectivity and importance in pest management. . In: Horowitz AR, Ishaaya I, editors. Insect pest management. BerlinHeidelberg: Springer-Verlag; p. 1-28. Doi: 10.1007/978-3-662-07913-3_1

Isman, M. B. 2006. Botanical insecticides, deterrents, and repellents in modern agriculture and an increasingly regulated world. Ann. Rev. Entomol. 51:45-66.

Doi:

10.1146/annurev.ento.51.110104.151146

Kabiri, M., Amiri-Besheli, B. 2012. Toxicity of Palizin , Mospilan and Consult on Agonoscena pistaciae Burckhardt and Lauterer (Hemiptera: Psyllidae), Oenopia conglobata L. (Coleoptera: Coccinellidae) and Psyllaephagus pistaciae Ferrière (Hymenoptera: Encyrtidae). Acad. J. Entomol. 5 (2):99-107.

Karagounis, C., Kourdoumbalos, A. K., Margaritopoulos, J. T., Nanos, G. D, Tsitsipis, J. A. 2006. Organic farming-compatible insecticides against the aphid Myzus persicae (Sulzer) in peach orchards. J. Appl. Entomol. 130:150-154. Doi: 10.1111/j.1439-0418.2006.01048.x

Kayser, H., Kaufmann, L., Schurmann, F. 1994. Pymetrozine (CGA 215, 944): a novel compound for aphid and whitefly control, an overview of its mode of action. Proc. Brighton Crop Prot. Conf. Pests and Diseases; Alton, Hants, UK, 1:737-742.

Khater, H. F. 2012. Ecosmart biorational insecticides: Alternative insect control strategies. In: Perveen F, editor. Insecticides: Advances in Integrated Pest Management. Croatia: InTech; p. 17- 60.

Koehler, C. S., Barclay, L. W., Kretchun, T. M. 1983. Soaps as insecticides. Calif. Agric. 37:11-12.

Kresting U, Satar S, Uygun N. 1999. Effect of temperature on development rate and fecundity of apterous Aphis gossypii Glover (Hom: Aphididae) reared on Gossypium hirsutum L. J. Appl. Entomol. $123 \quad$ :23-27. Doi: $\quad 10.1046 /$ j.14390418.1999.00309.x

Lawson, D. S., Weires, R. W. 1991. Management of European red mite (Acari: Tetranychidae) and several aphid species on apple with petroleum oils and an insecticidal soap. J. Econ. Entomol. 84:1550-1557. Doi: 10.1093/jee/84.5.1550

Layton, M. B., Gu, M. 2009a. Control of crape myrtle aphids on greenhouse-grown crape myrtle liners. Arthropod Manag. Tests. 34:G30.
Layton, M. B., Gu, M. 2009b. Efficacy of 'homeowner treatments' against whiteflies and mealy bugs. Arthropod Manag. Tests. 34:G40.

Lee, K. H., Chung, S. T., Chung, G. H. 2005. Effectiveness of bionatrol on control of two spotted spider mites (Tetranychus urticae), Aphids (Aphis gossypii), and whiteflies (Trialeurodes vaporariorum) on greenhouse grown English cucumber (Cucumis ssp. kasa). J. Kor. Soc. Hort. Sci. 46:241-245.

McKenzie, C. L., Puterka, G. J. 2004. Effect of sucrose octanoate on survival of nymphal and adult Diaphorina citri (Homoptera: Psyllidae). J. Econ. Entomol. 97:970-975. Doi: 10.1603/00220493(2004)097[0970:EOSOOS]2.0.CO;2

Miller, F., Uetz, S. 1998. Evaluating biorational pesticides for controlling arthropod pests and their phytotoxic effects on greenhouse crops. Hort. Tech. 8:185-192.

Mojeni, T. D., Rezwani, A. 2000. Study of the effect of some insecticides on aphids in cotton fields of Golestan province. 14th Iranian Plant Prot. Cong.; IRAN, 1:45.

Moore, W. S., Profita, J. C., Koehler, C. S. 1979. Soaps for home landscape insect control. Calif. Agric. $33: 13-14$.

Nuessly, G. S., Nagata, R. N. 2005. Evaluation of insecticides for control of green bug on seashore paspalum. Arthropod Manag. Tests. 30:G42. Doi: 10.1093/amt/30.1.G42

Perng, J. J. 2002. Life history traits of Aphis gossypii Glover (Hom., Aphididae) reared on four widely distributed weeds. J. Appl. Entomol. 126:97-100. Doi: 10.1046/j.1439-0418.2002.00613.x

Pesticides Database. 2014. Dioctyl sodium sulfosuccinate. Available from: http://www.pesticideinfo.org/Detail_Chemical.jsp? Rec_Id=PC33310.

Pinnock, D. E., Brand, R. J., Milstead, J. E., Coe, N. F. 1974. Suppression of populations of Aphis gossypii and $A$. spiraecola by soap sprays. J. Econ. Entomol. 67:783-784. Doi: 10.1093/jee/67.6.783

Ranaei, R., Emami, M. S., Valizadegan, U. 2012. Study on efficacy of some biorational pesticides on Aphis gossypii in greenhouse. 20th Iranian Plant Prot. Cong.; IRAN, 1:310.

Sadeghi, A., Van Damme, E. M., Smagghe, G. 2009. Evaluation of the susceptibility of the pea aphid, Acyrthosiphon pisum, to a selection of novel biorational insecticides using an artificial diet. J. Insect Sci. 9:1-8. Doi: 10.1673/031.009.6501 
Schuster, D. J., Stansly, P. A. 2009. Biorational insecticides for integrated pest management in tomatoes. Florida Cooperative Extension Service, University of Florida, ENY-684, pp. 1-9.

SAS Institute Inc. 2004. SAS/STAT user's guide. Version 9.1. Cary, NC, SAS Institute.

Smagghe, G., Mahdian, K., Zubrzak, P., Nachman, R. 2010. Antifeedant activity and high mortality in the pea aphid Acyrthosiphon pisum (Hemiptera: Aphidae) induced by biostable insect kinin analogs. Peptides, 31:498-505.

Doi: 10.1016/j.peptides.2009.07.001

Steppuhn, A., Baldwin, I. T. 2007. Resistance management in a native plant: nicotine prevents herbivores from compensating for plant protease inhibitors. Ecol. Lett. 10:499-511. Doi: 10.1111/j.1461-0248.2007.01045.x
Trdan, S., Žnidarčič, D., Valič, N. 2006. Field efficacy of three insecticides against cabbage stink bugs (Heteroptera: Pentatomidae) on two cultivars of white cabbage. International journal of pest management, 52, 2:79-87. Doi: $10.1080 / 09670870600568212$

Tremblay, E., Belanger, A., Brosseau, M., Boivin, G. 2008. Toxicity and sublethal effects of an insecticidal soap on Aphidius colemani (Hymenoptera: Braconidae). Pest Manag. Sci. 64:249-254. Doi: 10.1002/ps.1514

Wang, K. Y., Liu, T. X., YU, C. H., Jiang, X. Y., Yi, M. Q. 2002. Resistance of Aphis gossypii Glover (Homoptera: Aphididae) to fenvalrate and imidacloprid and activities of detoxification enzymes on cotton and cucumber. J. Econ. Entomol. 95:407-413. Doi: 10.1603/0022-049395.2.407 